\title{
READING OPEN EDUCATION IN THE AGE OF MANKIND: REPRODUCTION OF MEANING IN THE DERRIDEAN SENSE
}

\author{
Dr. Gulfem GURSES \\ Open Education Faculty, Anadolu University \\ Eskisehir, Turkey \\ Dr. Basak KALKAN \\ Open Education Faculty, Anadolu University \\ Eskisehir, Turkey
}

\section{ABSTRACT}

The rapid change in the communication technologies plays a significant role in the transformation processes of societies. The studies studying the industrial revolution in two phases inform us that the first phase of the revolution involved a revolution in machinery while the second phase saw a revolution in technology. Fast forwarding to the twentieth century, however, one of the areas that has been affected greatly from the said technological revolution is education. The structural changes in education are essential for a new educational process that is consistent with a heterogeneous student population and independent of time and space. In this respect, the new education system in information age has been come to be called open and distance education. In the $21^{\text {st }}$ century, when the information age gave way to the human age, we see learner oriented education system. Putting the learner at the center of the educational process, this particular system puts an end to binary opposition between the subject and object. Having aimed at identifying students' perception of open and distance education system being the educational technology of the twenty first century-, the present study has been conducted with 69 students that were presently enrolled to the Anadolu University Faculty of Open Education and entitled to the certificate of honor. A metaphor analysis method was employed within the scope of this study. In order to evaluate the students' perception of open education system, this study adopted a "phenomenological method" as its qualitative research method as it seemed to be more suited to its purpose. In order to identify the students' perception of open education system, they were given a semi structured questionnaire form that contained the following statement "Open Education is like ............ Because it is ................." and asked to convey their thoughts by focusing exclusively on a single metaphor. The answers from the participants were recorded by a camera, transcribed and analyzed through the spreadsheets created on an excel table. The participants of the study came up with 69 valid and 45 different metaphors regarding the concept of open education. Such metaphors were aggregated under 7 different conceptual categories. At the end of the study, it was established that the students enrolled to the Open Education System regarded open education as a means to access to information.

Keywords: Open education, distance education, metaphor analysis, Derrida, students' perceptions.

\section{INTRODUCTION}

Distance education left its mark in the educational systems of the developed and developing countries in the $20^{\text {th }}$ century. The most significant reason for such influence was the rapid development and expansion of the communication technologies. Today, technology, globalization and competitive dynamics influence all sectors of life. For this 
reason, the universities world over currently undergo a brand new transformation. In such transformation, however, popularization and information society assume a critical role. Rapid changes in the satellite, fiber optic, television, radio, computer, internet and various other information technologies affect the ways in which the education is conducted and force educators to implement new ways of teaching and learning. (Isman, 2011)

The $21^{\text {st }}$ century is associated with the society that produces and manages the technology rather than merely keeping up with it. All such developments are acknowledged as the name of the transformation observed in the $21^{\text {st }}$ century university. The name of this transformation is pronounced as the distance education system.

According to the United States Distance Learning Association (USDLA), distance learning is made available to the students living in remote areas by way of electronic devices that include satellites, computers, video and audio graphic multimedia technologies. Owing to the fact that the teacher and students are separated from one another geographically in the distance learning sessions, the educational programs in this form of education have to be conducted through the use of electronic devices and/or written materials. Distance education consists of two fundamental parts that involve teachers on the one hand and the students on the other hand (Ozbay, 2015).

As its definition indicates, distance education focuses on the interaction between the learner and teacher in the education process independently of time and space. The studies on distance education have gained a momentum due to the increasing importance of the distance learning practices and the increasing number of Open Universities and Open Education Faculties in the $21^{\text {st }}$ century. The studies thus far conducted seem to have mostly focused on the educational contents and process of distance learning. However, the learners constitute the most important pillar of the open/distance education system. In this respect, the learner's perception is deemed important in building the learning processes. This study, aiming to evaluate the students' perception of distance learning through a metaphor analysis, has studied the signs brought about by the distance learning sign and the reproduction of meaning in the word 'distance learning' on a conceptual level.

\section{READING DISTANCE LEARNING}

Known to both the contemporary teacher and leaner as the name of a new system, distance learning conjures up different concepts in the mindsets of both the learner and the teacher. The concepts such as distance education, open education, web based education, computer aided education and e-education are used as the synonyms of cyber education system. Albeit it is mostly based on practical reasons, such conceptual differentiation constitutes a significant debate for academic studies. While the concept of open signifies flexibility and choice in learning processes, the concept of distance signifies a mentality of education that is independent of time and space (Aydin, 2011).

The most important reason behind such conceptual differentiation is the presence of concepts that are peculiar to the fields of open and distance learning and the theories that attempt to account for the relationships between such concepts (Aydin, 2011).

In terms of system of words and signs, however, the concept of open education conjures up different definitions in the minds of the students and prospective students. Before moving on the discussion of the open education students' definitions of the subject, we believe it is important to address the views that interpret the $21^{\text {st }}$ century Open Education System through interaction and communication theories and as such theoretically contributed to the design of the education processes.

Hillary Perraton's theory on open learning is influenced by the philosophy of education, communication and diffusion theory. Claiming that open learning will help eliminate the 
limitations observed in the teacher and learners when they are all present at the same time and place, Perraton mostly focuses on the concept of distance rather than the concept of open. That being said, however, some of the other points made by Perraton such as the costs of the learning processes, size of the target audience in learning, changing nature of costs with the choice of technology, opportunity to reach out to those who can otherwise never be reached through the traditional education system, building an educational system that will include dialogue, transforming teacher into a person that makes learning easier, multiple learning environments and the processes that support various different student activities- draw parallels to the flexibility and choice aspects of the concept of open (Aydin, 2011).

The equivalence theory, put forward by Michael Simonson, maintains that it is a structured education system in which the learners are separate from one another as well as the teacher and educational resources and where communication between all elements is maintained through communication technologies (Aydin, 2011). By this approach, Simonson draws emphasis to the co-learning processes of the concept of distance that is independent of time and space and underscores the fact that the structured learning experience should not be different. However, the concept of learning experience, being the most significant component of the Equivalence Theory, includes the observations, emotions or activities that facilitate learning. The students that have been educated in different times and places may require mixed learning processes that offer different learning experiences. In this respect, the educational designs should be able to cater for different student groups who demand different experiences (Aydin, 2011). When considered in terms of the concepts of open and distance, it is seen that the system is built on the concept of open.

Assessing the theories of Simonson and Perraton, we note that the concepts of open and distance are employed together in shaping up the learning processes. However, what these two theories have in common is that they draw a particular attention to the flexible and optional learning experiences in designing the educational process. While the interaction and communication theories rely on the interaction between the teacher and learner, they transform the teacher into the agent that facilitates learning.

Due to the fact that open and distance learning is a new system; there are issues in identifying and explaining the concepts. An explanation intended for making people understand their life experiences in a certain area calls for a more in-depth explanation that is beyond the standard explanations ascribed to such experiences. In this respect, metaphors serve as systematic tools that contribute additional explanations to a concept and extend its application range. The metaphors developed freely by the study participants that allow to express their opinions and the analyses thereof enable us to achieve results in the open and distance learning related studies where the individuals are put at the center stage (Gunes \& Firat, 2016).

We believe that using metaphors will be more effective than other methods in getting through the thoughts of the study participants while conducting open and distance learning studies that involve different places, different socio-economic levels and a more heterogeneous target group, based on equivalence theory, as opposed to the traditional education system. Difficulty in reaching out to a greater audience, failure of the sample to represent the general population at all times and the superficial results found by the questionnaires may compromise the data collection process.

Identifying the meaning of the open and distance learning for the open education system students independently of the concepts of open and distance is considered important in terms of measuring the students' perceptions regarding this particular education system. Moreover, it is also important to measure the perceptual differentiation on the part of the students with respect to the open/distance learning. As Derrida points out, presenting the relationship between the being and subject by point out the differentiation relationship is 
considered important in terms of pointing out the fact that the internalization of the object is actually the internalization of the subject itself (Derrida, 2010).

\section{Derrida and Metaphor}

The word metaphor derives from the Ancient Greek word 'metapherein' which translates as moving forward or conveying. Latin rhetoricians converted the word metaphor into the word translatio or transferentia (Karamehmet, 2012). According to Nisanyan's dictionary of etymology, the word metaphor is used in the sense of "Transfer and transformation" in Ancient Greek, the languages into which it is adopted describe the word as "in rhetoric, the use of a word outside its naturally ascribed meaning, as in semantic shift"(Nisanyan, 2010). The both words above make noticeable reference to the sense of movement and conveyance (Karaahmet, 2012). In going from its etymological origin to its philosophical background, we see that the word metaphor is actually represents a vehicle whereby the word itself actually conveys the meaning from one place to another.

Metaphors have been influential in the fields of philosophy and literature theory for the last two thousand years. Plato was the first philosopher to address the metaphors in the superficial sense, while more sophisticated studies into them are found in the works of Nietzsche and Derrida. Having associated the concept of metaphor with the claims of superiority and will to power, Nietzsche believes that the metaphor will be destroyed once it is ascribed to its original meaning (Karaahmet, 2012). Derrida differs from all other thinkers who juxtapose the metaphor with the metaphysics of presence. Rejecting an independent realm of existence, Derrida argues that there cannot be a realm of meaning that is independents of signs.

The concepts of idea, substance, spirit of the world, god etc. all constitute the basis of a system of thoughts and forms where all other signs revolve around them. Derrida believes that every transcendental meaning along these lines is nothing more than a construct. There are certain signifies or meanings with respect to the signifiers such as Power, Freedom and Order that are given great importance in society. Sometimes such meanings are thought as if they were the origins of all other meanings. However, in order for such meanings to be valid, some other signifiers should have existed prior to such meanings. Whenever a source is thought of, there is always an immediate urge to go back to a starting point that precedes that source. However, such meanings cannot be seen by looking at the source, instead they can only be observed in line with certain purposes that spearhead the progression of all other meanings. One of the ways in which to comprehend the things in line with a purpose (telos) or teleology with reference to their etymology is to arrange the meanings in accordance with a certain hierarchy of meanings. Derrida suggests that every system of thought falling into the category of "metaphysics" is based on a pillar, foundation or an original principle. The original principles are, more often than not, described through "opposition" in relation to other concepts that are excluded by such principles. Such principles and the "oppositions" informed by such principles can always to subject to deconstruction (Sarup, 2004).

According to Derrida's language theory, signifier is not directly linked to the signified. There is no immediate reciprocal relationship between the signifier and the signified as espoused by the Saussurean philosophy. For Derrida, a word can never be one and the same with a thought. The signifiers and signifieds either disintegrate from one another or come together due to their being constantly involved in new combinations (Direk, 2004). Derrida argues that the meaning is not immediately crystal clear whenever a sign is read out. Signs point to absence and the meaning is in constant motion throughout a chain of signs. Also known as 'non-location', this suggests that the meaning is never dependent on a single sign (Sarup, 2004).

In his article titled 'Difference', which he published in 1968, (Derrida, 1968), Derrida -in reference to the irreducible doubleness of the Latin word "differe"- talks about a law of temporal and spatial differentiation that never reveals its true identity despite enabling 
signs to fulfill their functions. In talking about the 'difference' Derrida makes references to Nietzsche, Saussure, Freud, Levinas and Heidegger.

Defined as 'metaphorical' by Madan Sarup, difference holds that the meaning constantly revolves around the vicinity. Here, 'difference' is the description that is given to the process of 'meaning revolving around the vicinity'. In this respect, the biggest fear of the regular language is the reproduction of meaning. In summary, Derrida's philosophy of 'difference' is a structural principle that holds that a description is about the negative and positive references that it makes to other texts rather than the thing for which the description is given. Meaning changes over time, and, in the final analysis, the attribution of meaning is infinitely deferred. No text can be put aside, thinking that is already decrypted (Rosenau, 1998).

According to Derrida's philosophy and the chain of signs, while metaphor links the subject up to the object, it also remains present in the relationship between the being and the subject. For this reason, metaphor is the most interesting field of study in the social sciences today. In order to eliminate miscommunication, comprehension of deep metaphors regarded as essential today. Having been recognized by theoretical communication studies in terms of its efficiency, metaphor studies are now also employed by the educational communication studies. In this respect, an analysis of the age of mankind and the intellectual processes thereof are considered important in organizing the contents and patterns of the $21^{\text {st }}$ Century educational processes that currently undergo a significant transformation.

\section{METHOD}

\section{Purpose of the Study}

Acknowledged as the most significant signs that reveal the subconscious, metaphors enable us to get through one's subconscious. One can tell straightaway that a person likening academic life to a rescue boat has a different value judgment than a person that likens it to the sun. For this reason, metaphor analysis is considered important from designing educational processes to the marketing of educational services. This study aims to present the open and distance education students' perceptions on the open education system -which makes the biggest contribution to the expansion ratio of universities across Turkey- on a statistical level.

\section{Research Model}

This study is a phenomenological research conducted with a view to analyzing the metaphors expressed by the open education students with respect to their perception of the open education system. As a qualitative research method, the "phenomenological method" focuses on explaining the phenomena that we are aware of but yet have no detailed and in-depth knowledge of. Phenomena are presented to us in various ways such as in the form of events, experiences, perceptions, orientations, concepts and circumstances in the everyday life. However, this does not necessarily mean that such phenomena are fully understood. Phenomenology provides an appropriate research environment for the studies that aim to study the phenomena that we have some notion of but at the same time fail to fully comprehend (Yildirim \& Simsek, 2006).

The studies conducted by Gerald and Lindsay Zaltman (2008) suggest that human beings act based on more or less similar cognitive structures in every culture and society the world over. The studies of Gerald and Lindsay Zaltman show that the people living in various parts of the world express themselves by using the same "imitations" and metaphors. Zaltman and Zaltman have tried to identify common metaphors among people by developing a new technique. By conducting thousands of in-depth interviews in more than thirty countries, Zaltman and his team have come up with 7 fundamental metaphors that could establish associations with almost every sector, brand and product (Zaltman \& Zaltman, 2008). Zaltmans divide metaphors into two, namely metaphor themes and surface metaphors. Various studies show that people speaking in various languages use approximately five to six metaphors in one minute. Here, the metaphor themes serve as the common pillar that constitutes the basis of the similar surface metaphors. Metaphor themes are considered as the basis on which deep metaphors are elicited (Zaltman \& Zaltman, 2008). 
Study Group

In this study, conducted with a view to analyzing the Open University students' perceptions of the open education system on a statistical level, 65 students, enrolled to the Anadolu University Faculty of Open Education, were interviewed. The students in question were chosen randomly out of the students that were currently enrolled in the 3 faculties and associate degree programs of the Anadolu University Faculty of Open Education during the Academic Year 2015-2016. The number of students currently enrolled in the Anadolu University Faculty of Open Education during the Academic Year 2015-2016 was 1.435.754. (Open Education System, 2015) In determining the sample group for the study, the criteria developed by Pawson, Boaz, Grayson, Long and Barnes's (2003) with respect to the reliability and validity of qualitative researches were taken into account. Abbreviated as TAPUPAS, the model in question consists of the following criteria: transparency, accuracy, purposefulness, benefit, accessibility and genuineness. In this respect, the study was conducted with 69 students -of different age and professional groups that were currently enrolled in the various different departments/programs of the Anadolu University Faculty of Open Education- who were entitled to receive a certificate of honor.

Data Collection and Analysis

An interview form was prepared to elicit the metaphors that the students might have regarding the concept of Internet. While preparing the form, the studies where "metaphors were used as a tool" were reviewed as well. (Korkut \& Keskin, 2016; Korucu \& Yavuzaslan \& Usta, 2016; Demirpolat, Turpcu \& Koroglu, 2015; Yilmaz \& Guven, 2015; Franz \& Feld, 2015; Saban, 2009; Coulter, Zaltman \& Coulter, 2001) It was established that all of the studies thus reviewed asked the participants to complete the open ended sentences. Before collecting the data, the students were informed as to the metaphors without attempting to influence them in any way. The students were asked to complete the following sentence: "The open education system is like/similar to ................., because it is ......................". The answers given by the students were recorded by a camera and all the recorded interviews were later transcribed. The transcribed texts were then converted to excel spreadsheets. It was found that there were 45 valid metaphors. As a result of this study, and after having identified the conceptual categories based on Zaltman's metaphor themes and the characteristics pertaining to such categories, each metaphor was linked to the relevant category. At the end, 7 different conceptual category was identified. A coherency review was conducted to ensure the reliability of the study. During the data analysis stage, the researchers separated the metaphors into conceptual categories. And then an expert opinion was sought on the matter of qualitative research. The expert was provided with a list of metaphors in alphabetical order and the names of the determined conceptual categories. The expert was asked to match the metaphors with such conceptual categories. After having established the areas of agreement and disagreement with the expert, the Miles and Huberman formula (1994) (Reliability $=$ Agreement $/[$ Agreement+Disagreement]*100) was calculated. It was found that the coherence between the assessments of the expert and that of the researchers was around $92.75 \%$. Since the result of the calculation was found to be over 90 percent, the desired reliability for the present study was deemed to have been achieved.

\section{FINDINGS AND REMARKS}

The metaphors developed by the Open Education students regarding the concept of "Open Education" and the 7 different conceptual categories developed by Gerald Zaltman and L. H. Zaltman (2008) based on "Marketing Metaphors" and the characteristics pertaining to each category were identified with the support of the sample metaphors created by the participants.

According to the findings of this study, the participants of came up with $\mathbf{4 6}$ valid metaphors regarding the concept of open education. (Table 1) 36 metaphors out of 45 (magic wand, beehive, treasure-fountain of knowledge, river-brook, running water, heart, plane tree, life, energy, magician, universe-space shuttle, exterior house door, umbrella-roof, rescue boat, light, magic power, tool, hatchling, the old aunt that dispenses advice in the neighborhood, sportsperson, sky, live computer, Wikipedia, relay race, home, air, the place where dreams come true, ladder, flour mill, an invisible giant, my source of happiness, Venus, miracle, added value, smart friend, mate, love) were created by one participant only. The remaining metaphors, on the other hand, were created by 2 to 9 participants. These include the following metaphors: sun $(f=9)$, mother $(f=6)$, friend $(f=3)$, teacher $(f=4)$, family $(f=3)$, sea $(f=2)$, tree 
$(f=2)$, internet $(f=2)$, library $(f=2)$. The metaphors developed by the open education students regarding the concept of open education and the number of students representing such metaphors (f) and their respective proportional distribution (5) are provided in the Table 1 below.

Table 1. Metaphors created by the open education students regarding open education

\begin{tabular}{|c|c|c|}
\hline Metaphors & Frequency (f) & Percentage (\%) \\
\hline Library & 2 & $2.8 \%$ \\
\hline Mother & 6 & $8.6 \%$ \\
\hline Magic Wand & 1 & $1.4 \%$ \\
\hline Beehive & 1 & $1.4 \%$ \\
\hline $\begin{array}{l}\text { Library, fountain of } \\
\text { knowledge }\end{array}$ & 1 & $1.4 \%$ \\
\hline Sun & 9 & $13.04 \%$ \\
\hline Internet & 2 & $2.8 \%$ \\
\hline River, brook & 1 & $1.4 \%$ \\
\hline Heart & 1 & $1.4 \%$ \\
\hline Plane Tree & 1 & $1.4 \%$ \\
\hline Tree & 2 & $2.8 \%$ \\
\hline Life & 1 & $1.4 \%$ \\
\hline Energy & 1 & $1.4 \%$ \\
\hline $\begin{array}{l}\text { Friend (smart friend, } \\
\text { mate) }\end{array}$ & 3 & $4.3 \%$ \\
\hline Smart friend & 1 & $1.4 \%$ \\
\hline Mate & 1 & $1.4 \%$ \\
\hline Magician & 1 & $1.4 \%$ \\
\hline Teacher & 4 & $5.7 \%$ \\
\hline University, space shuttle & 1 & $1.4 \%$ \\
\hline Sea & 2 & $2.8 \%$ \\
\hline Exterior house door & 1 & $1.4 \%$ \\
\hline Umbrella, roof & 1 & $1.4 \%$ \\
\hline Rescue boat & 1 & $1.4 \%$ \\
\hline Light & 1 & $1.4 \%$ \\
\hline Magic power & 1 & $1.4 \%$ \\
\hline Tool & 1 & $1.4 \%$ \\
\hline Hatchling & 1 & $1.4 \%$ \\
\hline $\begin{array}{l}\text { Old aunt-uncle that } \\
\text { dispenses advice in the } \\
\text { neighborhood }\end{array}$ & 1 & $1.4 \%$ \\
\hline Sportsperson & 1 & $1.4 \%$ \\
\hline Sky & 1 & $1.4 \%$ \\
\hline Live computer & 1 & $1.4 \%$ \\
\hline Relay race & 1 & $1.4 \%$ \\
\hline Home & 1 & $1.4 \%$ \\
\hline Air & 1 & $1.4 \%$ \\
\hline $\begin{array}{l}\text { The place where dreams } \\
\text { come true }\end{array}$ & 1 & $1.4 \%$ \\
\hline Ladder & 1 & $1.4 \%$ \\
\hline Family & 3 & $4.3 \%$ \\
\hline Flour mill & 1 & $1.4 \%$ \\
\hline An invisible giant & 1 & $1.4 \%$ \\
\hline My source of happiness & 1 & $1.4 \%$ \\
\hline Venus & 1 & $1.4 \%$ \\
\hline Miracle & 1 & $1.4 \%$ \\
\hline Added value & 1 & $1.4 \%$ \\
\hline Wikipedia & 1 & $1.4 \%$ \\
\hline Love & 1 & $1.4 \%$ \\
\hline TOTAL: 45 & 69 & $100 \%$ \\
\hline
\end{tabular}


The characteristics of deep metaphor categories were identified by reviewing the deep metaphor categories developed by Gerald Zaltman and L. H. Zaltman (2008) -which include balance, transformation, journey, container, connection, source and control- and the subjects, sources and the relationship between the subjects and sources of the metaphors created by the participants. The deep metaphor patterns and their respective characteristics are provided in the Table 2 below.

Table 2. Seven Conceptual categories regarding open education system and the characteristics that represent them

\begin{tabular}{ll}
\hline Categories & Characteristics of Open Education System \\
\hline Balance & $\begin{array}{l}\text { Open Education is dynamic. } \\
\text { Open Education maintains the balance. } \\
\text { Open Education addresses the question of balance. }\end{array}$ \\
Transformation & $\begin{array}{l}\text { Open Education serves to fulfill some important requirements such as } \\
\text { self-realization and attainment of social superiority. } \\
\text { Open Education facilitate the transformation for those coming from } \\
\text { different value systems. } \\
\text { Open Education ensures a reliable transformation. } \\
\text { Open Education brings about natural transformations. } \\
\text { Open Education brings about magical transformations. }\end{array}$
\end{tabular}

Journey

Open Education is a journey to a known destination.

Open Education is a journey to the unknown.

Open Education helps me overcome barriers.

Open Education shows me the path to success.

Container

Open Education is a physical, psychological and social environment.

Open Education reads my mind.

Open Education is culture.

Open Education is protective.

Connection Open Education helps me strengthen my social ties

I am at ease within the Open Education system.

Source Open Education shows me how to accumulate the things happening around me.

Open Education shows me how to distribute the things that I've accumulated around me.

Open Education shows me how to share the things that I've

accumulated.

Control Open Education does not limit my freedom.

Open Education is balanced.

Open Education is the source.

(Prepared based on the work "Marketing Metaphoria" by Gerald Zaltman, L. H. Zaltman, 2008)

The list of metaphors created by the participants in accordance with the 7 conceptual category regarding the concept of open education and the characteristics thereof is provided in the Table 3 below. 
Table 3. Distribution of the Metaphors According to Categories

\begin{tabular}{ll}
\hline Categories & Metaphors \\
\hline Balance & $\begin{array}{l}\text { Added value to life, life, family }(n=3) \text {, friend }(n=3) \text {, river- } \\
\text { brook-running water }\end{array}$
\end{tabular}

Transformation Internet $(n=2)$, tool, magic wand, live computer, flour mill, the place where dreams come true, smart friend, hatchling

Journey Ladder, umbrella, roof, rescue boat, magician, life, space shuttle, friend $(n=3)$, love, relay race, sportsperson, sea

Container Wikipedia, internet $(n=2)$, library, big library, family, space shuttle, universe

Connection Mother $(n=6)$, exterior house door, a friend living in a faraway place but who I can reach anytime I want, heart

Source Sun $(n=9)$, air, source of happiness, old aunt in the neighborhood, teacher $(n=4)$, teacher reflected on the mirror, smart friend, tree, Venus, mother $(n=6)$, plane tree, energy, treasure, fountain of knowledge, beehive, light, internet

Control

Sky, exterior house door, an invisible giant, sea

The participants created seven metaphors for the balance metaphor. Such metaphors include value added to life $(f=1)$, life $(f=1)$, family $(f=3)$, friend $(f=3)$, river-brookrunning water $(f=1)$. The examples of the metaphors created within this category are given below.

\footnotetext{
"Added value to life"

"Everything learned in life is an added value to the life." And the thing that provides that added value is the Open Education faculty. It is a great added value for those with limited time and resources. It helps you improve your quality of life."

"Life, life itself, one gets to know oneself through education."

"A person realizes their potential as they educate themselves. People discover the purpose of life through education. As you get educated, you think to yourself whether I can do more for other people's lives."

"Family"

"Renews its services every day. I think they are doing everything they can to make us successful."

"Family"

"I pick up the knowledge that I'm missing. I like doing research. I think of it as a big family. It's always with us"

"Friend"

"As I'm currently enrolled in a distance learning course right at home it's like a family member in our household, $I$ always have the open education textbooks open... I'm doing tests in the workbook; it's like a friend under my hand."

"A Friend"

"I see it as a friend to whom I can talk freely and blow off some steam."

"Friend"

"As I'm currently enrolled in a distance learning course right at home it's like a family member in our household, I always have the open education textbooks open... I'm doing tests in the workbook; it's like a friend under my hand."

"River, brook, running water"

"By reaching the unreachable areas, education fulfills its duty of teaching. Considering the places it goes, I'd say it's like water that runs cleanly, clearly, uninterruptedly and rapidly, meeting the requirements. Considering that knowledge is of vital importance, it can reach everywhere, bringing life to everybody."
} 
Balance is considered to be one of the earliest metaphors developed by people. Having started life with fundamental biological, mental, moral and social balance oriented capabilities, individuals build a mentality of social and moral balance on top of their physical balance (Zaltman \& Zaltman, 2008). For this reason, individuals are in search of various different sources of balance that will meet their requirements. Since the biological, mental, moral and social balance is, more often than not, intricately intertwined, the search of balance within any of these four areas of balance has an effect on other remaining areas of balance. The participants that came up with the friend metaphor show that the open education has answered for their search of social balance. The dynamic nature of the search of balance finds its expression in the metaphors of river and running water. Having been defined as an entity that constantly renews itself, the open education system addresses to the dynamic mankind's search of balance.

With respect to the transformation metaphor, the participants created 8 metaphors. These include the internet, tool, magic wand, live computer, flour mill, the place where dreams come true, a smart friend and hatchling. The examples of the metaphors created within this category are given below.

\author{
"Internet" \\ "With open education it is possible for you to continue with learning \\ without having to be confined within a particular place, boundary or \\ timeframe." \\ "It is a system that tests my success, motivates and supports me and at the \\ same time makes me see myself as my rival. Anadolu University Faculty of \\ Open Education means my personal success." \\ "A tool" \\ "It is a means and a tool that enables people to reach their goals, objectives \\ and dreams. \\ "Magic Wand" \\ "In order to make dreams come true" \\ "Live computer" \\ "It enables us to continue our activities in life and better ourse/ves." \\ "A Flour Mill" \\ "It reminds me of a process that requires hard work, like a flour mill. For \\ me. It brings forth a product gradually through hard work." \\ "The place-environment where dreams come true" \\ "I see it as an environment where every means is made available for those \\ of us who are enrolled in a distance learning program." \\ "Hatchling" \\ "It gets to know the air and water and then it develops and learns to fly \\ freely. It ensures improvement in its field." \\ "I can liken it to a smart friend." \\ "This friend is an immense source of information; you can learn things from \\ him. You can obtain information from him as long as you want; he is your \\ friend and he is always there for you."
}

Presence or absence of transformation functions as a strong, automatic and subconscious way of evaluating one's experiences (Zaltman \& Zaltman, 2008). Transformation is considered to be the most influential parameter in people's lives. Most of the literary works, from Holy Scriptures to tales, in essence, tell the story of the transformation of the universe. As in the case of the metaphor of balance, in the metaphor of transformation, too, physical transformation influences social transformation as well. When the concept of open education is evaluated within the framework of the characteristics of the transformation metaphor, the participants point out through the metaphors they have created that the open education has guided their transformation processes. 
With respect to the metaphor of journey, the participants created 11 metaphors. These include ladder, umbrella, roof, rescue boat, magician, life, space shuttle, friend $(f=3)$, love, relay race, sportsperson and sea.

The examples of the metaphors created within this category are given below.

"Relay race"

"I endeavor to carry the flag I've received to the highest level possible."

"Ladder"

"It made me achieve the success I'd desired step by step. It gave me the opportunities that had been previously denied to me."

"Umbrella, Roof"

"You both study and be with your family at the same time. It makes you move up in the world."

"Rescue boat"

"After having graduated from high school, I could not get further education due to political reasons, as I was wearing headscarf at the time, but this provided me an opportunity."

"Love"

It is like love. It makes us look ahead with hope.

"Magician"

It is a great opportunity for those who missed out on education in the past, thinking they could make up for it in the future, or those who lament about not having studied when they had the chance"

"Sportsperson"

"Just like a sportsperson who cannot run a racetrack in his first attempt. But he gets better and better in time. He gets the experience. Open Education provides us with that experience."

"Sea"

"Everybody can access the information easily from everywhere and depending on their own capacity; it is like those who swim well go further away in the sea but those who can't stay behind the shore."

"Friend"

"I spend time with him, he keeps me company."

"As I'm currently enrolled in a distance learning course right at home it's like a family member in our household, I always have the open education textbooks open, I'm doing tests in the workbook; it's like a friend under my hand."

Journey is one of the topics that piques people's interest the most. The journey themes are important in terms of underscoring the thoughts that people have in mind. The meaning emphasized in the proposition " $I$ 'm rapidly coming close to my graduation day" is different from the meaning emphasized in the proposition "my graduation day is rapidly coming close" (Zaltman \& Zaltman, 2008). According to Zaltman and Zaltman, the first proposition has an intermediary element. A person moves towards a certain timeframe and event. In the second proposition, however, the event moves towards a person. The important thing to consider here is the accurate analysis of the trajectory between the subject and agent and the object and agent. The answers given by the participants for the metaphors they created indicate the destination of the movement. However, it should be noted that in the deeply intertwined metaphors, the binary opposition between the subject and object will be eradicated. When the metaphor of journey is evaluated in terms of the characteristics determined for the purposes of this study, we see that the students identify the open education as a known journey. However, with the metaphor of "love", we see that they identify a journey to the unknown. The common ground for all of the participants is that the open education is a means of overcoming obstacles and a path to success. Another deep meaning associated with the metaphor of journey is that we can embark on a journey with others just like we can do on our own and do it for the good of others or ourselves. Those who create the metaphor of friend are the proof that they 
regard the open education system as a journey by identifying the concept of open education with the metaphor of friend.

With respect to the metaphor of container, the participants created 7 metaphors. These include Wikipedia, internet $(f=2)$, library, big library, family, space shuttle and universe. The examples of the metaphors created within this category are given below.

\author{
"I liken it to the internet" \\ "With open education it is possible for you to continue with learning \\ without having to be confined within a particular place, boundary or \\ timeframe." \\ "It is a system that tests my success, motivates and supports me and at the \\ same time makes me see myself as my rival. Anadolu University Faculty of \\ Open Education means my personal success." \\ "Universe-space shuttle" \\ "It is an unlimited universe of learning. It is a universe of learning, the \\ boundaries of which we can imagine for ourselves; it is a potent device. It \\ is like a space shuttle that takes us to the place we wish to go, a strong \\ vehicle." \\ "Wikipedia" \\ "I think it is beneficial to us like bedside books." \\ "Family" \\ "Family is always very important for me, for me the school is like family" \\ "I liken it to a library" \\ "I can find every information I need there." \\ "I can liken it to a big library" \\ "I pick up the information I'm missing through there. I love doing research \\ very much. I think of it as a big family. It's always with us."
}

With the metaphor of container, life is seen as a container. Individuals see themselves and the objects and events around them in the form of containers. The requirements that individuals have managed to meet or failed to meet are each a container. Since an individual's life is a container, their memories, emotions and thoughts are considered as containers as well (Zaltman \& Zaltman, 2008). In this respect, Zaltman and Zaltman defines university as a container that has a biosphere of its own and in which the students wish to plunge into both socially and academically. When the qualities of open education are viewed within the framework of the metaphor of container, we come across the following propositions: open education is a physical, psychological and social environment, open education reads my mind, open education is culture, open education is protective. The students defining open education in the form of a container liken the open education system to a container into which they wish to go in and which supports their betterment. Those associate it with the metaphor of family regard the open education system as a protective container. However, we should note that the participants who created the metaphor of family appear to be at odds with the deep meaning of freedom. The metaphor of family also seems to give the impression of being stuck in the inner container, as opposed to the metaphors such the internet which describes, rather, an outer container.

With respect to the metaphor of connection, the participants created 4 different metaphors. These include mother $(f=6)$, exterior house door, a friend living in a faraway place but who I can reach anytime I want and heart. The examples of the metaphors created within this category are given below. 
"I liken it to a good mother, a caring mother."

"She provides me with everything, thinks of everything else. She reaches out to anyone anytime."

"Mother"

"It is as caring, trustworthy, happy and altruistic as mother, a university that has the scent of a mother."

"A mother"

"It embraces me like a mother, provides me opportunities like a mother."

"Mother"

"I've learned everything I know from my mother. Likewise, I can say that I've learned everything I know academically from the Open University.

"Exterior House Door"

"It is like the exterior house door, intertwined with the garden outside, it's as if I can find every information and everything that $I^{\prime} m$ looking for there. I'm at peace there, it doesn't upset me, I'm on my own and plan the way I'd like to go about my education."

"Like a friend that lives in a faraway place but you can reach anytime you want"

"I can call up my faculty directly and talk to them and make our complaints matter. I feel that we are not left to our own devices, despite the fact that we study physically away from the classroom we got to see our deans and chancellors."

"It is the heart of the higher education mechanism."

"It is the lifeline of education in every aspect."

Individuals possess a basic urge or requirement which is defined by the sense of being connected and sometimes being disconnected (Zaltman \& Zaltman, 2008). The origins of this urge are traced back to the history of evolution and found in the process of sustaining the existence. For this reason, the sense of belonging is firmly entrenched in the behavioral patterns as a permanent urge. Ever since the conception, the sense of connection that is originally started with the umbilical cord guides our interaction with the social and physical environment. For this reason, when the deep meanings of the metaphors created herein are viewed, we see that they hint at a sense of connecting with the self and also with the outside world. Those defining the concept of open education with the metaphor of mother betray the urge of connection that originally started in their mother's womb. Through the connection conveyed by the metaphor of balcony between the inner world and outer world, the participants seem to regard open education as a safe connection between the comfort of the interior and distrust of the exterior. When we study the influence of the metaphor of connection on individuals, we see that individuals make connections between the events taking place around them. The participant that defines open education as the heart of the higher education system uses a strong metaphor to make connection between the Open Education System and other higher education programs and establishes the connection between himself and the open education system through a vital organ, namely the heart.

With respect to the metaphor of source, the participants created 17 different metaphors. These include sun $(f=9)$, air, source of happiness, old aunt in the neighborhood, teacher $(f=4)$, teacher reflected in the mirror, smart friend, tree, Venus, mother $(f=6)$, plane tree, energy, treasure, fountain of knowledge, beehive, light and internet. The examples of the metaphors created within this category are given below.

"Sun"

"It is like the sun that warms and enlightens me and makes me feel alive as it has given me the opportunity to resume my career without delay and supported me and helped me out at every turn."

"Sun"

"It never lets you lose hope. Like you know there is light at the end of the tunnel, you know it will rise up like the sun." 


\section{"Sun"}

"It holds light to my career, I study and work at the same time. When I finish school, it will help me immensely in getting promoted at work" "Sun"

"It lightens up the area and enlightens the people in that area without realizing them."

"Air"

"I think of it like the air for those who do not have the chance to study at school but compelled to do so at home. Just like you won't be able to live without breathing you cannot survive without education."

"My source of happiness"

"I'm one of those people that love studying so much. Open education is right up my alley. I love doing homework. I feel content when I'm studying."

"I liken it to the old uncles or aunts that tell tales or dispense advice in the neighborhood."

"It guides our way."

"A very valuable instructor/teacher... he is not there with you but you feel as though its reflection was in the mirror or projected through the mirror"

".... It gives us very valuable information, and therefore enlightens our world like the rays of the sun. It gives us life. Because life without science and knowledge is possibly the biggest dark abyss that one can find himself in. It is unique in that it takes us out of that bottomless hole."

"I can liken it to a smart friend."

"This friend is an immense source of information; you can learn things from him. You can obtain information from him as long as you want; he is your friend and he is always there for you."

"Tree"

"We can be the fruits or branches of that tree. We, too, become useful to others by dropping into soil from that tree and becoming a tree ourselves." "Light"

"I'd say it is enlightenment. It enlightens everyone through education, puts people one step ahead in their career, help them overcome the obstacles in their path."

"It is like a venerable, deep rooted and centuries old plane tree, under the shade of which you can lie down."

"It embraces people with the knowledge it provides, you can keep the knowledge you acquired for decades."

"I can liken it to a beehive or a mother or a house."

"It's broadened my horizon, teaching me everything. "

"It's like treasure, a fountain of knowledge"

"It gives us opportunities to better ourselves without going to school. It is a significant opportunity, a treasure."

"Venus"

For me, Open Education is the light of hope; it is the path to achieving $m y$ goals or, rather, the goals that I have changed for the future."

Zaltman and Zaltman (2008) define sources in the form of capabilities and skills that are used in achieving certain goals. In this respect, the concept of open education is regarded as more than a mere educational institute. The participants go so far as to describe it as a guide, life changer, a torch that casts light. As for the accumulation, reproduction and distribution of knowledge, the participants describe the open education with the metaphors of sun, mother, teacher and light, which involve dissemination and augmentation. By using the metaphors of beehive, treasure and fountain of knowledge, we get the impression that they associate the concept of open education with the accumulation of knowledge. 
With respect to the metaphor of control, the participants created 4 different metaphors. These include sky, exterior house door, an invisible giant and sea. The examples of the metaphors created within this category are given below.

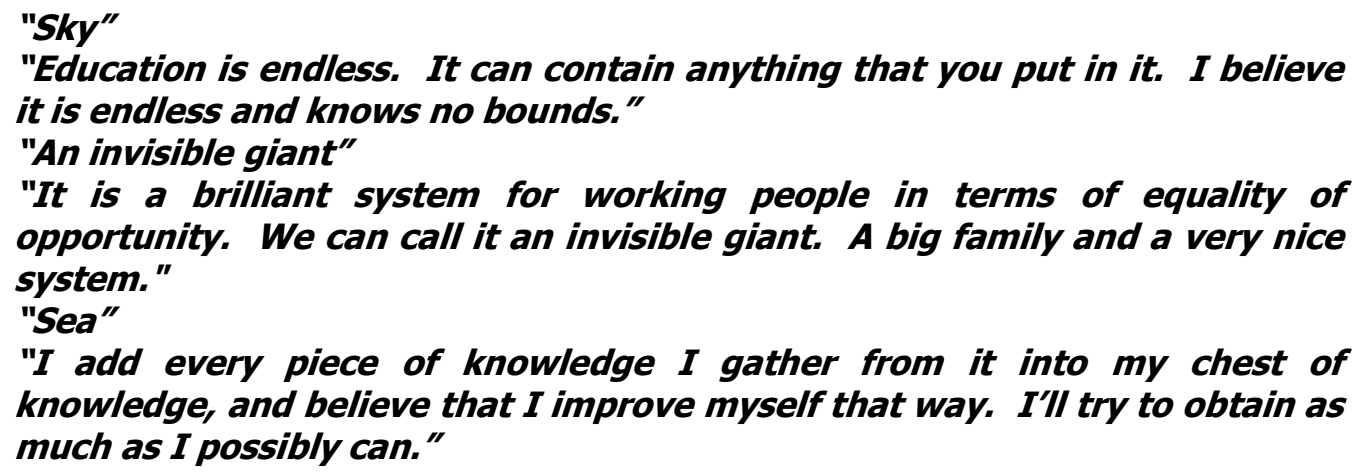
knowledge, and believe that I improve myself that way. I'll try to obtain as much as I possibly can."

The deep metaphor of control is triggered by the subconscious urge to control ourselves and the events around us (Zaltman \& Zaltman, 2008). This subconscious urge to control things causes anxiety when people face with the situations that they cannot control. When the metaphor of control is evaluated in terms of its qualities associated with the concept of open education, we see that the participants describing the open education system with the metaphors of sky and sea regard the concept of open education as something that does not limit their freedom. However, in describing it in the form of an endless sky, they hint at losing their grip on control. The metaphor of invisible giant, on the other hand, suggests that they see it as a giant that protects them against the uncertainties resulting from the situations occurring out of their control. The participant that makes reference to the equality of opportunity seem to suggest that the giant will defend their rights and thereby maintain the balance in the event of an unexpected risk or inequality. In this respect, the deep metaphor of control appears to be working in tandem with the metaphors of balance and source.

The participants created 45 different metaphors for the concept of open education, which were classified in 7 different categories as per their respective characteristics. Another attention grabbing finding of this study is the availability of common areas where deep metaphors intersect with one another. As seen in the case of the deep metaphor of control working in tandem with the metaphors of balance and source, there are many metaphors that work in coordination with each other. The deep metaphors that work with each other are presented in the table 4 below.

Table 4. Intertwined Metaphors

\begin{tabular}{llc}
\hline Metaphors & Categories & (f) \\
\hline Family & Balance, container & $\mathbf{3}$ \\
Internet & Transformation, container, source & 2 \\
Mother & Connection, source & 7
\end{tabular}

Friend, mate Transformation, journey, connection, source 5

When the intertwined metaphors are evaluated, the metaphor of family that describes the concept of open education appears to be working with the metaphors of both container and balance. While the metaphor of internet is working with the metaphors of transformation, container and source; the metaphor of mother works with the metaphors of connection and source; and the metaphor of friend with the metaphors of transformation, journey, connection and source. 
If the fulfilled and unfulfilled requirements of an individual are described in the form of a container, the participant that describes the concept of open education with the metaphor of "family" also attributes the qualities associated with family -that is the qualities that maintains his physical and mental balance- to the concept of open education and thereby identifies open education with family, a unit that helps shape up his mental container, memories, emotions and thoughts. In this respect, while the open education corresponds to the search of balance it also works with container as well.

While the metaphor of "internet" serves as a vehicle for important requirements such as self-realization and attainment of social superiority, it also describes a physical, social and psychological environment through the metaphor of container. In addition to the metaphors of transformation and container, the metaphor of internet also defines the accumulation and distribution of knowledge through the metaphor of source.

While the metaphor of "mother", on the other hand, describes the Open Education System as a comfortable and reliable structure, it also describes it as a system that accumulates and augments knowledge through its deep metaphors.

The metaphor of "friend" works with the deep metaphors of transformation, journey, connection and source. Catalyzing transformation for those coming from different value systems, the Open Education System is also described as a journey that helps people overcome obstacles. While it makes social connections work through the metaphor of connection, the deep metaphor of source is coded by the participants through sharing the accumulation of knowledge.

\section{CONCLUSION}

According to the findings of the present study that aimed at presenting the open education students' perceptions of the open education system, the metaphors of sun, family, friend, mother and teacher have been found to be have been created by multiple participants. It has been established that the metaphors created by a single participant are mostly included in the category of source. The most frequently created metaphor has been identified as the metaphor of sun. When the deep metaphor of source is evaluated in terms of its characteristics associated with the accumulation, reproduction and distribution of knowledge, we see that the participants that are currently enrolled in the Open Education system tend to think of the system along the lines of a source of obtaining knowledge. The frequency of the use of metaphor of family, on the other hand, appears to correspond to their effort to maintain social balance or their search of social and physical balance. The fact that the metaphor of family also corresponds to the deep metaphor of container shows that the concept of open education also describes a psychological and social environment as well. However, it should be noted at this point that the deep metaphor of container also represents a sense of entrapment in the subconscious. Considering the frequency of the use of the metaphor of mother, the metaphor of mother coded within the metaphor of connection describes both a comfortable and secure structure under the supervision of the mother and also a certain structure within the vicinity of the container.

It is believed that the strength of deep metaphors in measuring perception paves the way for creating the contents of a system. However, another equally important point is the presentation as to how the individual improvement and transformation processes -as the key objectives of education- will be built. The metaphors created within the category of transformation focuses on natural and miraculous transformations. Making the deep metaphors of transformation and connection work together in the studies intended for developing the academic contents and communication strategies of the Open Education system will be important. 
Although they are accounted for through their different characteristics, deep metaphors always work together. Such combination calls for congruity and integration rather than conflict. Conceptual harmonization sheds light to the emotional states of individuals that are brought forth through their subconscious. The concept of conceptual harmonization, introduced by Zaltman and Zaltman (2008), is likened to the combination of the colors of yellow and blue. Through the combination of the colors of yellow and blue comes the color green. However, we know that the origin comes from the colors yellow and blue. In this respect, the joint working of the metaphors of transformation and journey in the metaphor of friend can be given as an example. For a student that had to take a time out from their education due to family reasons, open education provides the opportunity of a brand new journey, helping him overcome obstacles; for an individual coming from a different value system it presents a chance to realize himself. For this reason, it is important that deep metaphors are read on top of one another, rather than individually, in order to elicit subconscious meanings.

\section{BIODATA and CONTACT ADDRESSES of AUTHORS}

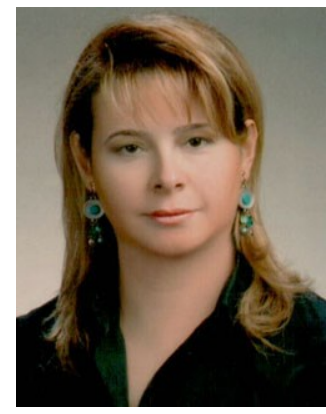

Dr. Gulfem GURSES is an assistant professor at Anadolu University Open Education Faculty. She received her Ph. D. in Radio-TV-Cinema University of Istanbul. She has been working as a TV director in Educational Television Production Center at Anadolu University. She produced many instructional, educational TV programs and documentary films.

\section{Dr. Gulfem GURSES}

Department of Distance Education, Open Education Faculty

Anadolu University, 26470, Eskisehir, TURKEY.

Phone: +90 222335058010 ext. 2396

E- mail: gulfemg@anadolu.edu.tr

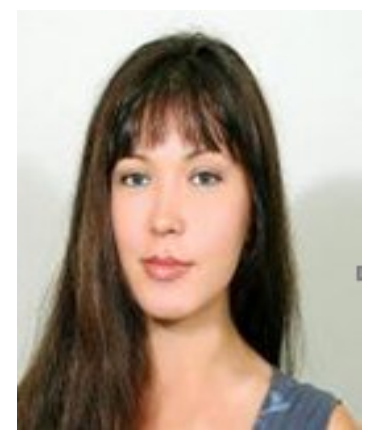

Dr. Basak KALKAN is a lecturer at Anadolu University Open Education Faculty. She was graduated from Istanbul University Faculty of Political Sciences, Public Administration Department in 2002. She received her PhD degree on "Female Politicians in Turkish Policy and Coding of Female Politicians in Media" in 2012. The major field of her studies is women studies, cross cultural studies, communicational gap of distance education tools and discourse analyses. Since 2010, she is a scriptwriter at Department of Distance Education and Educational TV in Anadolu University Faculty of Open Education. She designed and wrote many educational TV programs.

\section{Dr. Basak KALKAN}

Department of Distance Education, Open Education Faculty

Anadolu University, 26470, Eskisehir, TURKEY.

Phone: +90 222335058010 ext. 2394

E-mail: badar@anadolu.edu.tr

\section{REFERENCES}

Aydin, C.H. (2011). Acik ve Uzaktan Ogrenme Ogrenci Adaylarinin Bakis Acisi. [Open and distance learning students' perspectives] Ankara: Pegem Akademi.

Coulter, R.A., Zaltman, G. \& Coulter, K. S. (2001). Interpreting Consumer Perceptions of Advertising: An Application of the Zaltman Metaphor Elicitation Technique. Journal of Advertising, Volume XXX, Number 4, 1-22. 
Demirpolat, B., \& Turpcu, M. \& Koroglu, M.G. (2015). Meslek Yuksekokulu Ogrencilerinin Meslek Yuksekokuluna Iliskin Algilarinin Metaforlar Araciligiyla Analizi. [Analysis of Vocational School Students' Perceptions about Vocational Schools through Metaphors] Electronic Journal of Vocational Colleges-4. UMYO, 202-209.

Derrida, J. (1968). Difference. Retrieved from http://projectlamar.com/media/Derrida-Differance.pdf

Derrida, J. (2010). Gramatoloji. [Grammatology] Ankara:Bilgesu Yayıncilık.

Direk, Z. (2004). Derrida'nın Dusuncesinin Fenomenolojideki Kaynaklari. Cagdas Fransiz Dusuncesi, [Phenomenological Resources of Derrida's thought. Contemporary French ideas/thoughts] Ankara, Epos Yayınları.

Franz, M. \& Feld, T. C. (2015). The status of continuing higher education at German universities: a metaphor analysis, Journal of Adult and Continuing Education, Volume 21 No. 2. Retrieved form http://dx.doi.org/10.7227/JACE.21.2.6.

Gunes, A. \& Firat, M. (2016). Acik ve Uzaktan Ogrenmede Metafor Analizi Arastirmalari. [Performing Metaphor Analysis in Open and Distance Learning], Acikogretim Uygulamalari ve Arastirmalari Dergisi AUAd, 2(3), 115-129.

Karaahmet, B. (2012). Kurumsal Iletisimde Metafor. [Metaphor in Corporate Communication] İstanbul:Beta Basım.

Isman, A. (2011). Uzaktan Egitim. [Distance Education] Ankara: Pegem Akademi.

Korkut, A. \& Keskin, I. (2016). Universite Ogrencilerinin Kariyer Algilari: Metaforik Bir Analiz Calismasi. [Career Perceptıons of Unıversity Students: A Metaphorıcal Analysıs] Mustafa Kemal University Journal of Graduate School of Social Sciences, 13 (33), 194211.

Korucu, A.T. \& Yavuzaslan, I.F. \& Usta, E. (2016). Ortaogretim Ogrencilerin Artirilmis Gerceklik Uygulamalari Hakkinda Urettikleri Metaforlar. [Metaphors Created By Secondary Education Students Regarding Augmented Reality Applications] Journal of Subject Teaching Research (ALEG) Cilt 2 Sayı 2, 81-89.

Miles, M. B. \& Huberman, A. M. (1994). An Expanded Sourcebook Qualitative Data Analysis. ThousandOaks, California: Sage Publications.

Nisanyan, S. (2010). Sozlerin Soyagaci. Istanbul: Everest Yayinlari.

Open Education System (2015). Range of Students in 2015-2016 Fall Term in Open Education System. Eskisehir: Anadolu University.

Ozbay, O. (2015). Dunyada ve Turkiye'de Uzaktan Egitimin Guncel Durumu. [The Current Status of Distance Education in The World and Turkey] The Journal of International Education Science, 2(5), s. 376-394.

Pawson, R., Boaz, A., Grayson, L., Long, A. \& Barnes, C. (2003). Types and quality of social care knowledge. Stage two: towards the quality assessment of social care knowledge. ESRC UK Centre for Evidence Based Policy and Practice: Working Paper 18. Retrieved from https://www.kcl.ac.uk/sspp/departments/politicaleconomy/ research/cep/pubs/papers/assets/wp18.pdf.

Rosenau, P. M. (1998). Post-Modernizm ve Toplum Bilim/eri. [Post-modernism and the Social Sciences] Ankara: Ark Yayinlari. 
Saban, A. (2009). Ogretmen Adaylarinin Ogrenci Kavramina Iliskin Sahip Olduklari Zihinsel Imgeler. [The Metaphorical Images that Prospective Teachers Have on the Concept of the Student] Turk Egitim Bilim/eri Dergisi, 7(2), 281-326.

Yildirim, A. \& Simsek, H. (2006). Sosyal Bilimlerde Nitel Arastirma Yontemleri. [Qualitative Analysis for Social Science] Ankara: Seckin Yayincilik.

Yilmaz, G. \& Guven, B. (2015). Ogretmen Adaylarinin Uzaktan Egitime Yonelik Algilarinin Metaforlar Yoluyla Belirlenmesi. [Determining the Teacher Candidates' Perceptions on Distance Education by Metaphors] Turkish Journal of Computer and Mathematics Education, 6(2), 299-322.

Zaltman, G. \& Zaltman, L. (2008). Marketing Metaphoria: What seven deep metaphors reveal about the minds of consumers. Boston, Massachusetts: Harvard Business School Publishing. 